UDC 82.09

DOI: 10.26565/2521-6481-2019-4-7

\title{
THE CONQUEST AND RESISTANCE, A WOMAN AND A MAN: FEMINIST AND IMAGOLOGICAL READING OF W. S. MAUGHAM'S “THE UNCONQUERED”
}

\author{
MA in Philology, PhD student in Philology \\ National University of Ostroh Academy \\ 2 Seminarska Street, Ostroh, Rivne region, 35800, UKRAINE \\ e-mail: khrystyna.semeryn@oa.edu.ua \\ ORCID: 0000-0003-0112-7719
}

(C) Khrystyna SEMERYN

\begin{abstract}
:
In the paper, the national and women's contexts closely interrelated in W. S. Maugham's “The Unconquered" short story (1943) are being examined. While analysing the ground of the conquest and resistance, it is concluded that war conquering and sexual violence are aimed to establish the men's power over certain part of the world. In some ways, capturing a woman and occupying the land are considered equal things under the patriarchal rules. With this in mind, any male conqueror tries to reach both of them not only for the sake of victory, but also for approval his status of a worthy member of a men-ruling society (a nation). Next, the role of stereotypes as an engine of all negative phenomena of national and gender non-understanding, in particular, war and various kinds of inequality, is stressed. Tracing the complex relationship between, on the one hand, Frenchmen and Germans, and women and men, on the other hand, it should be token that the final infanticide is multivalued whereas it means the woman's liberation and revenge for the men's world, as well as is an apogee of national resistance.
\end{abstract}

Keywords: imagology, nationalism, stereotypes, the woman issue, the World War II, W. S. Maugham.

\section{Introduction}

The Unconquered, a short story of the prominent British novelist William Somerset Maugham, had released in his Creatures of Circumstance last collection (1947). This is, according to Sina Movaghati, "the riveting accounts of the dramas of love, jealousy, revenge, and murder, filled with eccentric Freudian cases and enigmatic detective stories" (57). Here, events take place in France during the War World II. With regard to, characters represent diverse types of people not profound persons, in particular, the Conqueror, the Unconquered, and the Collaborator, which are interesting, however, not restricted for imagological perception. Certainly, The Unconquered examines crucial (C) Semeryn K., 2019

This is an open-access article distributed under the terms of the Creative Commons Attribution License 4.0.

Semeryn, K. (2019). The Conquest and Resistance, a Woman and a Man: Feminist and Imagological Reading of W. S. Maugham's "The Unconquered". Accents and Paradoxes of Modern Philology, 1(4), pp. 109-119. doi: 10.26565/2521-6481-2019-4-7 
national and personal issues: freedom, captivity, slavery, conqueror complex, servility, violence, etc. In Imagology: On Using Ethnicity to Make Sense of the World, a modern theorist of Imagology Joep Leerssen outlines:

Ethnicity is never operative in isolation, just by itself. A person or character with a given ethnicity always possesses more attributes than only that ethnicity. [...] Ethnotypes never function by themselves; they always work in conjunction with other frames, especially gender, age and class (26).

The author argues that the mechanism of state conquest operates within the same framework and utilizes the similar means as a man gets power and rules over a woman in the typical patriarchal society. In The Unconquered, both phenomena are clearly tied although it does not mean that nationalism is equal to men power, indeed. The main task of this essay is thus to probe Maugham's short story through the lens of imagological, and feminist approaches in order to realize how literature constructs personal, and national narratives based on the same models of conquering, power and resistance.

In the story, two levels-national and gender-display a double gist of the conquest. Certainly, this duality is a special feature of Maugham's story whereas national projections of Frenchmen and Germans allow denouncing together the generic vices of patriarchal society, and the horror of Nazism, obviously. Likewise, it reflects the complexity of relationship between a woman and a man in terms of nationalism rooted in the gender inequality, and sexual interaction, the more so it always fixes the strict gender roles inside the society.

In order to explore the strategies of national and gender interactions under the power issue, there two literary approaches mainly are being utilized. The first is imagology, which is directed towards inscribed national characters, or ethnotypes, international relation, with national stereotypes as its generic parts. Feminist critics is the second one, which means allow examining the woman question within the framework of "national” theme. Author's basic assumptions imply the nationalist grounds of Nazi led to generalization of national level within the story. Gender roots of any national struggle is almost undisputable subject whereas it functions ipso facto as the approval of power of "the stronger over the weaker," which initially implies gender roles, and stereotypes towards a "strong male conqueror," and a "weak dependent woman." The fact that this is true women are still believed to serve sexual slaves and mothers of Nation's "sons” regardless of their affiliation and desire.

\section{The InterNational Context: Reflecting the Self in a Mirror of the Other}

In the literary praxis of Maugham, the story occurs within the Nazi framework. According to Anthony Smith, Adolf Hitler conceptualized the Nation around the frequently iterated notion of Ethnie, namely German Volk (in Weaver). As Jon Cai Benjamin Weaver comments on it, "The core of the volk was the Aryan nuclei that represented the pure breed of the German people. This term volk, with its mystic overtones of primeval forests and dark tribal instincts, combines ethnocentric, national and racial connotations" (Weaver). Although many sharply deny the connection between nationalism and Nazism, a limited impact of the nationalist principles on Nazism is indisputable, in particular

Semeryn, K. (2019). The Conquest and Resistance, a Woman and a Man: Feminist and Imagological Reading of W. S. Maugham's "The Unconquered". Accents and Paradoxes of Modern Philology, 1(4), pp. 109-119. doi: 10.26565/2521-6481-2019-4-7

https://periodicals.karazin.ua/accentsjournal 
separated radical ideas. Probably, between any nationalist theory and Nazi ideology, there emerged similar myths of members of nation shared the ancestry, common history and cultural memory, identity, etc. That is something, which firmly unites all people because the mythical and real oneness is a crucial condition of community existence. From the very beginning, W. S. Maugham partially examines the national principles and content of Nazism. In the story, Germans precisely play a part of the Conqueror confirming this assumption by the permanently used self-determinations: "the victors" and "the conquering army."

From "German" point of view, which is equivalent, due to imagological theory, to the meta-image, there is not a true image of German culture. Beyond telling us the tensions between Hans and Willi, the narrator displays felonious Hans's actions against both old Périers, which witnesses his hatred towards any people who is conquered or simply weaker. Further story of his relationship with Annette belongs to the framework of gender interaction, in spite of adopting the national context. He, for instance, clearly shows Hans' contempt for Willi’s “weakness,” as well as Annette’s inaccessibility considering it unnatural and tabooed in terms of nationalism. Obviously, the exemplary hero's racial “purity,” aggressive masculinity and blind faith in Nazism truly make him an "ideal Nazi.” Rejecting "Nazi" context, Hans epitomizes the idea of a proper German of that time and, definitely, of an ideal conqueror established absolute power over the conquered. Certainly, a mentioned property focuses on the unity of national and gender stereotypes anticipating the specified imago mundi. A wellrounded German picture of the world, as any national view primarily based on stereotypes, centers around the points of "good and bad." With this in mind, I argue Hans and Willi perhaps are the opposite doppelgangers personified given facets of the German ethnotype although the reciprocal is relative: obviously, what is proper idea for the Nazi world is abnormal thing for humanity. Consequently, the inner and external dissimilarities between Hans and Willi mirror the contradictory essence of any national image, in the case, German. Following Maugham, Hans is a tall blue-eyed and blonde-haired man, with a "sunny grin," instead Willi is vice versa "a little fellow, dark and thinfaced," admiring Hans because "he was so tall, slim and broad-shouldered, because his curly hair was so fair and his eyes so blue" (Maugham 276-277). Moreover, Hans and Willi represented the pairs of opposites, such as strong and weak, beautiful and ugly, wild and civilized, in particular, Willi epitomizes the civilized part of German society, etc. This evidences the deep conflict in the core of the ethnotype. Evaluating the world with the given "property," Germans clearly reject not suitable all. Hans believe Frenchmen are "decadent people," which relates to their otherness. He does not accept Annette's appearance as something "intimidating." Reluctance to experience live communication is the foremost reason of non-acceptance of the Other, for instance Hans thoughts about French girls, “mercenary and hard as nails” (278), determined only by soldier gossips.

By contrast, textual images of Frenchmen mirror two patterns, the Conquered and the Unconquered, within the sole national environment. Adopting national stereotypes, "French" vision of Germans, the aforementioned meta-image, maintains natural aggression against the German enemies, consequently, Annette's attitude was an apogee of which. Remarkably, parents (old Périers) represent the Conquered, at the same time children (Annette, her dead brother and her murdered fiancé, Pierre

Semeryn, K. (2019). The Conquest and Resistance, a Woman and a Man: Feminist and Imagological Reading of W. S. Maugham's "The Unconquered". Accents and Paradoxes of Modern Philology, 1(4), pp. 109-119. doi: 10.26565/2521-6481-2019-4-7

https://periodicals.karazin.ua/accentsjournal 
Gavin) subject the Unconquered. Annette's father is defeated by younger and stronger Hans, in the interim, her mother supporting the collaboration for the sake of material welfare and safety. Annette, the only alive Unconquered deeply resists the enemies although all men of her family, who "could never have borne the shame of defeat," are dead (284). In comparison, old Périers became favorable to Hans quickly after getting food and other provision from him.

To some extents, inscribed German-French encounters during the WWII have several dimensions, especially a struggle between Nazi German and anti-Nazi states, and, more global, between the Conqueror and the (Un)Conquered. Despite the proclaimed differences between Germans and Frenchmen, there are obscure evidences of national association, for instance, farmer's roots of both Hans and Annette.

Based on national stereotypes, which are changeable, there emerged the phenomenon of xenophobia, viz., Germanophobia, as well as certain Francophobia. "While the semantic content of stereotypes can remain stable over centuries, the qualities expressed in them can be positively or negatively evaluated depending on whether the observed country is seen as friend or foe” (Mittermaier 137). Yet, the exemplary transformation of Germanofilia of the first decade of XX ct. into Anti-German sentiment is axiomatic. The (artificial) intercultural opposition of French and German has reached the importance in the light of the specified notion of Order. Frequently, German believed to bear the order while stereotyped Frenchmen "are” the passionate, chaotic nation, German propaganda thus focuses on this and other artificial oppositions for incitement to hatred and contempt.

You ought to understand that this is the best thing that has ever happened to the French people. We didn't declare war. You declared war. And now we're going to make France a decent country. We're going to put order into it. We're going to teach you to work. You'll learn obedience and discipline. (Maugham 278)

The order is associated with the property of Nazi imago mundi, "the new order that Hitler was going to create in Europe" therefore means a hypothetical ordering of all things. Hans considers Frenchmen to be "weak and decadent" people because of the absent imaginary order.

In addition, it is an important observation that intercultural interplay is only possible if people would try to communicate better. For instance, Willi speaks French well and have been working at Paris for two years, therefore, he is able to deeper understanding the another nation. However, this is invalid until one does not speak the same language as Hans who had demanded Annette to understand his German, endeavoring to impose his vision of the world as the only possible. The hidden focus of the narrative places on the great role of adequate, respectful communication between nations as the only solution to the war. Annette most appreciates intelligence, which connects with a civilization per se. That is why she indeed proclaimes the freedom and dignity, above all stressing that, "Others may despise me. I will never do anything that can make me despise myself. You are my enemy and you will always be my enemy. I only live to see the deliverance of France” (297). Baring the problem of collaboration, Maugham sees it as the specified way of communication in the unequal war circumstances. Annette's parents clearly support Hans for the sake of food and provisions.

Semeryn, K. (2019). The Conquest and Resistance, a Woman and a Man: Feminist and Imagological Reading of W. S. Maugham's "The Unconquered". Accents and Paradoxes of Modern Philology, 1(4), pp. 109-119. doi: 10.26565/2521-6481-2019-4-7 
Consequently, national images of Germans and Frenchmen are the complex textual constructs much influenced the mutual stereotypes and the difficulties of communication with the Others.

\section{The Gender Context: to Conquer a Woman, not to Understand}

A woman occupies the place of an object in the proper Nazi world, which is ruled by men. In the volume of Gender Ironies of Nationalism. Sexing the Nation, Tamar Mayer points out that "nationalism becomes the language through which sexual control and repression (specifically, but not exclusively, of women and homosexuals) is justified, and masculine prowess is expressed and exercised” (24). Apparently, inscribed German power is men-centered at all levels. It implies strict gender attitude of men and women towards each other and rigid gender requirements, foremost, to the female part of society. In the overview, Zarana Papic contends,

Various nationalist ideologies promote an aggressive and violent masculinity whose barbaric behaviour is justified in the name of each Nation's cause. When human rights are annihilated in this way, women's rights are deleted and women are reduced to being seen as wives and mothers who will breed and rear future defenders of the Nation. (115)

Annette became a fatal victim of such order being not only the (formally) conquered by the enemy, but also the mother of a future "defender" of the new, Nazi German nation, in which she was brushed by force. Hans clearly associates the order with men, he therefore considers they "haven't got enough men in France to work the land you've got” (209). Nevertheless, this confirmation has a propagandist base since "It's well known that you. A fellow gave us a lecture the other day at Soissons. He said that a third of the farms were left uncultivated because there aren't the men to work them" (290). Believing in similar order of patriarchal society, Madame Périer worries about the future of their estate without man. Let us look at the characteristics of such the "men's" world, frequently named as "traditional society" in the East Europe where traditions are equal to the nation-based patriarchal system humiliating women, homosexuals and other weak people. In the circumstances, German soldiers possess the fundamental attributes of superiority, that is foremost military and physical power.

Generalizing the women's issues mirrored in the narration, there is a need of assumption that Annette defends not only her country, but also the borders of her own women's world, although this struggle is not entirely consistent. Indeed, Hans personifies the hostile to a woman environment based on patriarchal values where clear men's and women's roles could not been changed. Stereotypical male mode of behavior captures demonstrative masculinity, cruelty towards weak people, military and sexual abuse. I see how the formation of gender identity, which inscribed in the traditional view as sex-determined, depends upon the ethnonational implications and expectations. "You're a man, aren't you?" - Hans asks the weaker Willi, later finishing his rhetoric with, "Stupid, that's what you are. Ein Weibchen. A woman” (276-277). That clearly confirms that social expectations of man's behavior cover brutality and aggressive masculinity whilst woman's part covers weakness and obedience. Annette's reluctance to obey Hans highly contradicts the socially acceptable pattern of female behavior thereby it greatly annoyed him. Remarkably, a man fully justifies his actions, as it is

Semeryn, K. (2019). The Conquest and Resistance, a Woman and a Man: Feminist and Imagological Reading of W. S. Maugham's "The Unconquered". Accents and Paradoxes of Modern Philology, 1(4), pp. 109-119. doi: 10.26565/2521-6481-2019-4-7

https://periodicals.karazin.ua/accentsjournal 
always a woman's fault. “...All this wouldn’t have happened if the girl hadn't been a fool”, Hans speculates blaming Annette for his own crime against her (277). There are many external selfexplanations, such as drinking, the conqueror complex, delight of "the great victories of the German armies", fatigue, finally "the circumstances," as Hans meant it (288), however, the permissiveness and general tolerance of men's violations are per se the main argument. For this reason, sometimes women advocate anti-feminine traditions even more stubbornly than men do, since it allows keeping status quo. Annette's mother remains the most consistent protector of national men-centered traditions though offends her violated daughter.

What have you got against the boy? He took you by force-yes, he was drunk at the time. It's not the first time that's happened to a woman and it won't be the last time. He hit your father and he bled like a pig, but does your father bear him malice? (Maugham 294)

What is more, sexual crimes against women also are justified by society due to the strong belief that a woman must like any man, which pay attention to her.

In addition, the entanglement of gender identification relate to social masks, whose the exemplary case is Hans' meeting with a dog. While Hans realized his complete power over pregnant Annette, whose parents were on his side, he had no reason to proceed the pretending to be good in Périers' eyes, he therefore got rid of the social mask of an "almost good” man.

Now as the dog ran towards him, irritably giving way to his feeling of frustration, Hans gave it a savage, brutal kick and the dog was flung into the bushes and limped yelping away. "The beast," she cried. “Lies, lies, lies. And I was weak enough to be almost sorry for him.” (Maugham 298)

The great part of the women's context in the story belongs to the issue of female sexual objectification crucial in the monotheist civilization. In her groundbreaking work The Second Sex, Simona de Beauvoir considered that during the adolescent age a girl:

Becomes an object and she sees herself as an object; she discovers this new aspect of her being with surprise: it seems to her that she has been doubled; instead of coinciding exactly with herself, she now begins to exist outside (Beauvoir 316).

Through the objectification Annette and hypothetical German woman, Hans displays national differences between German and French cultures, in spite of prejudices and inscribed gender inequality. "She wasn't his type. She wasn't very pretty” (286), he believes, comparing Annette with "tall and full-breasted, blue-eyed and fair-haired like himself" German women. Discrepant appearance, obviously, is a reason of initial non-acceptance the Other, although in the patriarchal civilization, this episode evidences the "natural" role of a woman as a thing for man's pleasure and a mean of gaining the higher social status. Hans considers Anette to be a "doll” for entertainment, whose feelings do not matter, indeed. He therefore firstly paid "a hundred francs so that mademoiselle can buy herself a new dress" (279) and later on, took Annette "a pair of silk stockings to show there was no ill-feeling" (280). However, he afterwards evaluates Annette as a thing for his status enhancement as she is an intelligent teacher, "almost a lady"; hereupon, in the letter to parents, Hans

Semeryn, K. (2019). The Conquest and Resistance, a Woman and a Man: Feminist and Imagological Reading of W. S. Maugham's "The Unconquered". Accents and Paradoxes of Modern Philology, 1(4), pp. 109-119. doi: 10.26565/2521-6481-2019-4-7 
wrote that he "was going to marry a French girl and with her a fine farm" (292). The last specification shows that the social value of a woman remains entirely related with her dowry. Unfortunately, she is an addition only to the property of her parents and the future property of her husband.

In sum, the retention of strict gender patterns and social rules is an obligatory condition of national self-preservation. Aforementioned aspects therefore indicate the complexity of man-woman relations and actually evidence an abyss between real human equality and the nationalist imago mundi.

\section{The Sexual Context: a Gender Gist of the Conquest}

In her overview of nationalism and gender, Masculinity and Nationalism: Gender and Sexuality in the Making of Nations, Joane Nagel stresses that "state power, citizenship, nationalism, militarism, revolution, political violence, dictatorship, and democracy - are all best understood as masculine projects, involving masculine institutions, masculine processes and masculine activities" (243). She exposures "the intimate historical and modern connection between manhood and nationhood" and resumed that there are the "patriotic manhood and exalted motherhood as icons of nationalist ideology” (Nagel, 242). According to Nagel, it means par excellence that nationalism designates the special gendered "places" for men and women in national politics, causes the domination of masculine interests and ideology in nationalist movements, and manifests the sexualized militarism through "the construction of simultaneously over-sexed and under-sexed 'enemy' men (rapists and wimps) and promiscuous 'enemy’ women (sluts and whores)” (Nagel, 242).

The episode, when Hans and Annette are involving, reproduces this thought in full. German's symbolic self-confirmation of victory occurred while Hans was riding through the Arc de Triomphe on his motorcycle in the first time. Arc emblematizes the female genitals; thereby riding epitomizes a metaphorical act of penetration that means, at the same time, the conquest of the state. Violated the girl, Hans reached the second stage of the symbolic conquest.

After enslaving her body, he simply uses Annette's womb for growing his son and tries to enslave her will and life via a forced marriage, which would become the apogee of his power over the woman. For this reason, he is so happy when he had heard about Annette's pregnancy. Despite this, Hans' inability to realize the felonious implications of his attitude is the remarkable observation. Narrowly speaking, it is an example of traditional male impunity for crimes against women; broadly speaking, this evidences the existence of a great communicative abyss between men and women, as well as between differ nations. Probably, "fool" is the symbolic reference to this issue illustrating the impossibility of mutual understanding.

Oh, come, daughter, the time has passed for foolishness. You must be realistic. Pierre is dead. Hans loves you and wants to marry you. He's a fine-looking fellow. Any girl would be proud of him as a husband. How can we restock the farm without his help? He's going to buy a tractor and a plough with his own money. You must let bygones be bygones (Maugham 294).

The aforecited appeals to gender communication gap: mother does not understand Annette's pain whilst Hans definitely called the act of raping as the "misunderstanding." It is also an instance of the

Semeryn, K. (2019). The Conquest and Resistance, a Woman and a Man: Feminist and Imagological Reading of W. S. Maugham's "The Unconquered". Accents and Paradoxes of Modern Philology, 1(4), pp. 109-119. doi: 10.26565/2521-6481-2019-4-7

https://periodicals.karazin.ua/accentsjournal 
great social depreciation of women because there emerged a general idea that any woman would be happy to have sex with any man who is "not a bad-looking." The typical belief toward homosexual men, which are contended to want the relationship with any man, in the post-Soviet countries is the same example. Intending to disguise criminal premises of conquerors' actions (and in general) as female fatal implication, Madame Périer and Hans both aspire bargaining the profit from the symbolic and physical selling Annette's body. Old Périers would get a certain guarantee of secure comfortable life while Hans get a new family, land and a farm, a son.

He remembered a French proverb. C'est le premier pas qui coûte. There's nothing to cry about, old woman. It had to come sooner or later (Maugham 279).

Obviously, capturing a woman and conquering the land means per se the same things to any male conqueror who is guided by patriarchal values. Moreover, every "full" man have to perform these two acts for approval of the own "man's" status leveling the role of sex and war as the manifestations of the conquest, the key meaning of which is the establishment of male power in the world. Finally, it should be token that an assault on Annette is a felony although all characters try to avoid the truth under the patriarchal and war circumstances.

\section{The Infant's Context: the Infanticide as an Extreme Mean of Resistance}

Deeply rooted in mythology, foremost the Biblical story of the sacrifice of Isaac, infanticide narration is widely used in XX century literature, for instance, in George Eliot's Adam Bede (1859), Vasyl Stefanyk's The News (1899), Sam Shepard's Buried Child (1978), Tony Morrison's Beloved (1987) etc. In Isaac and Oedipus: A Study in Biblical Psychology of the Sacrifice of Isaac, following Freud's idea of "primordial patricide," namely killing a brutal primordial father by his humiliated sons, Erich Wellisch supposes that "before primordial patricide there probably was primordial infanticide” (10). Regarding this, there emerge the same allusive motif of a struggle between Hans and Mr. Périer, in which a younger competitor won the right to own the world of an older competitor.

Being conceived by the conqueror, Annette's body turned into a point of intersection at least the following five contexts: gender relations, man violence, and military conquering, Nazi, motherhood. On the subject of, Annette's fetus approves German military victory over France and Hans' man victory over Annette, guaranties the continuation of his aggressive masculinity, approval of the Nazi world, and permanently reminds about the sexual violence made her happy motherhood impossible, being thus more an idea or a symbol than an alive infant. That is why Hans is happy: "It was his child she bore in her womb" (285); after all, a son would confirm his status of a worthy man in traditional society, as well as his victory over the defeated country. Despite this, the child means a great threat for Annette as a reminder of violence against her and of her rapist, and a visual proof of her “collaboration."

There are no clear evidence when Annette decided to exactly kill the child; however, her attitude towards Hans have been changing during her pregnancy. Firstly, she hated him after being assaulted; hatred and silence represent an absence of communication with the Alien, a clear sample of negative communication, which has often the dangerous implications for all nations. Next, not in the last turn,

Semeryn, K. (2019). The Conquest and Resistance, a Woman and a Man: Feminist and Imagological Reading of W. S. Maugham's "The Unconquered". Accents and Paradoxes of Modern Philology, 1(4), pp. 109-119. doi: 10.26565/2521-6481-2019-4-7

https://periodicals.karazin.ua/accentsjournal 
presumably, because of the reasons of pressure of her parents, German occupation, chemical transformation inside her body ultimately, Annette is almost ready to forgive Hans for the crime. Taking into account, in many respects, the mythological basis of the infanticide motive, there various mythological sub-contexts function in the story. At this point, the narrative, to some extents, echoes the patriarchal myth of Odysseus and Penelope. Symbolic Odysseus, Hans, is a promiscuous wanderer appearing from time to time at her home whilst symbolic Penelope, Annette, is humbly waiting for him, whiling the days with sewing. Probably, the scene with the dog ruined this illusion; yet, after seeing this, Annette symbolically turned into Medea, whose aim is only a revenge, thus finally transformed from the patriarchal addition to the man into a full-fledged woman. Notwithstanding, her transformation was not consecutive at all points whereas her attempt to get rid of fetus by seeking a doctor for abortion evidences it. There emerges another notable thing: during the searches for medical aid, Madame Périer was helping her daughter owing to the patriarchal taboo of a child out of wedlock, albeit later, she realized a profit of the future child and changed her line.

Without an attempt of justifying the infanticide, I suppose that Annette's son could not hence be alive, in any case, while she and the others "unconquered" resist the conquerors. Overcoming her maternal feelings and a fear of committing a crime, Annette eventually decided to defend her own dignity, personal and national freedom in the only way she could do it.

It is worth noting, mentioned drinking of German soldiers has a special significance in the story. At the very beginning, a drunken man, Hans, rushed into Annette's house and reigned there through beating the chief man, Annette's father, establishing his power in the fetus inside Annette's body. In the end, when Annette killed the infant, Hans indeed lost more: his alive son looked like his father, therefore, he further "like a drunken man flung out of the door" (300). Probably, it is a kind of symbolic revenge: for the man's crime against the heroine and for the crimes of Nazi Germany towards France globally.

\section{Conclusions}

Summarizing the paper, The Unconquered is dedicated to multidimensional reflection the events during the World War II, which made the national and women's contexts intertwined. At the national level, there emerged the problem of non-understanding (communicative abyss) determined by patriarchal patterns of men's behavior, which cover the modes of power, aggressive masculinity and violence towards the weak people, as it appears in the Nazi imago mundi. Meanwhile, at the personal level, patriarchal values strongly influence the life of women and men maintaining the strict gender roles, forasmuch a woman should behave as the weak addition to men. Any war conquest therefore has a sexual core, representing a conqueror as a strong man, a conquered state as a weak nation, simultaneously a woman, and the conquering, a victory as a sexual assault and an act of penetration. Furthermore, the final act of infanticide has completed two main strategies of struggling for freedom: woman's resistance to the patriarchal world and her overcoming the man's power, as well as national resistance to the continuation of the conqueror's power over the motherland. Eventually, levelling the relationship between nation-states and between people is possible, to a certain extent, because of the

Semeryn, K. (2019). The Conquest and Resistance, a Woman and a Man: Feminist and Imagological Reading of W. S. Maugham's "The Unconquered". Accents and Paradoxes of Modern Philology, 1(4), pp. 109-119. doi: 10.26565/2521-6481-2019-4-7 
sole mechanism of power and subordination, when women (and weak people, additionally) mostly play a role of subordinated. It generates the similar dangerous implications of non-acceptance and non-understanding the Others whether it would be another cultures or people, different from the white male men.

\section{REFERENCES}

Beauvoir, S. de. (1961). The Second Sex. New York: Grune and Stratton.

Leerssen, J. (2016). Imagology: On Using Ethnicity to Make Sense of the World. Les stéréotypes dans la construction des identités nationales depuis une perspective transnationale, 10, pp. 1331.

Maugham, W. S. (1955). The Complete Short Stories of W. Somerset Maugham, Vol. I. London: William Heinemann Ltd.

Mayer, T. (ed.). (2000). Gender Ironies of Nationalism: Sexing the Nation. London; New York: Routledge.

Mittermaier, Ute Anna. (2007). No More than Human by Maura Laverty: Impressions of a Reluctant Governess in Spain. Estudios Irlandeses, 2, pp. 135-150.

Movaghati, S. (2016). What Goes Around, Comes Around: The Manifestation of Peripeteia in Maugham's The Unconquered. International Journal of Comparative Literature \& Translation Studies, 4, 4, pp. 57-59.

Nagel, J. (1998). Masculinity and Nationalism: Gender and Sexuality in the Making of Nations. Ethnic and Racial Studies, 21, 2, pp. 242-269.

Pageaux, D.-H. (1981). Une Perspective D'études en Littérature Comparée: L'imagerie Culturelle. Synthesis, VIII, pp. 169-185.

Papic, Z. (1994). Nationalism, Patriarchy and War in Ex-Yugoslavia. Women's History Review, 3, 1, pp. 115-117.

Weaver, J. C. B. (2011). Adolf Hitler's account of the 'Nation' and 'Nationalism.' [Blog] EInternational Relations Blog. Retreived from at: https://www.e-ir.info/2011/05/16/adolfhitlers-account-of-the-\%E2\%80\%98nation\%E2\%80\%99-and\%E2\%80\%98nationalism\%E2\%80\%99/\#_ftn1

Wellisch, E. (1954). Isaac and Oedipus: A Study in Biblical Psychology of the Sacrifice of Isaac. London: Routledge.

Article submitted on 25 September 2019.

Accepted on 17 October 2019.

Semeryn, K. (2019). The Conquest and Resistance, a Woman and a Man: Feminist and Imagological Reading of W. S. Maugham's "The Unconquered”. Accents and Paradoxes of Modern Philology, 1(4), pp. 109-119. doi: 10.26565/2521-6481-2019-4-7 


\title{
ЗАВОЮВАННЯ І СУПРОТИВ, ЖІНКА І ЧОЛОВІК: ФЕМІНІСТИЧНЕ ТА ІМАГОЛОГІЧНЕ ПРОЧИТАННЯ «НЕСКОРЕНОЇ» В. С. МОЕМА
}

(C) СЕМЕРИН Христина Дмитрівна

\author{
магістр філології, аспірант \\ Начіонального університету «Острозька академія» \\ вул. Семінарська, 2, м. Острог, Рівненська обл., 35800, УКРАЇНА \\ e-mail: khrystyna.semeryn@oa.edu.ua \\ ORCID: 0000-0003-0112-7719
}

\section{Анотація:}

У статті досліджено взаємопов'язані національний та жіночий контексти новели В. С. Моема «Нескорена» (1943р.). На основі аналізу мотивів завоювання і супротиву зроблено висновок, що військове завоювання й сексуальне насильство мають на меті встановити владу чоловіків над певною частиною світу. У патріархальному дискурсі підкорення жінки та захоплення території розглядають як певною мірою рівнозначні дії. 3 огляду на це, кожен чоловікзавойовник намагається досягти обох цілей не лише заради перемоги, а й задля утвердження свого статусу як гідного члена суспільства (нації), де панують чоловіки. Крім того, авторка 3'ясовує роль стереотипів як рушіїв негативних явищ національного та гендерного характеру нерівності, насилля і війни. Простежуючи складні взаємини між, з одного боку, французами і німцями, а, з другого боку, - між жінками і чоловіками, наголошено, що, зрештою, фінальне дітовбивство набуває кількох тлумачень: позначає визволення жінки та помсту чоловічому світові й, одночасно, уособлює апогей національного супротиву проти нацизму.

Ключові слова: імагологія, націоналізм, стереотипи, жіноче питання, Друга світова війна, B. C. Моем.

Статтю подано 25 вересня 2019.

Схвалено до публікації 17 жовтня 2019.

Semeryn, K. (2019). The Conquest and Resistance, a Woman and a Man: Feminist and Imagological Reading of W. S. Maugham's "The Unconquered". Accents and Paradoxes of Modern Philology, 1(4), pp. 109-119. doi: 10.26565/2521-6481-2019-4-7 